\title{
Biomass Production and Potential Fixed Nitrogen Inputs from Leguminous Cover Crops in Subtropical Avocado Plantations
}

\author{
Terry J. Rose ${ }^{1,2, *(D)}$ and Lee J. Kearney ${ }^{1,2}$ \\ 1 Southern Cross Plant Science, Southern Cross University, Lismore, NSW 2480, Australia; \\ lee.kearney@scu.edu.au \\ 2 Centre for Organics Research, Southern Cross University, Lismore, NSW 2480, Australia \\ * Correspondence: terry.rose@scu.edu.au; Tel.: +61-2-6620-3457
}

Received: 17 December 2018; Accepted: 2 February 2019; Published: 5 February 2019

\begin{abstract}
Nitrogen $(\mathrm{N})$ fertiliser is applied to perennial horticultural crops to increase yields, but subsequent $\mathrm{N}$ losses in subtropical plantations may be high due to intense rainfall and warmer temperatures. While legume cover crops could potentially contribute $\mathrm{N}$ to the tree crops and reduce fertiliser-N requirements, few studies have quantified potential fixed-N inputs from cover crops legumes in tropical or subtropical tree crop systems. To address this, we investigated growth and $\mathrm{N}$ fixation of summer-growing Pinto peanut (Arachis pintoi Krapov. \& W. C. Greg cv. Amarillo) and winter/spring dominant white clover (Trifolium repens L. cv. Haifa) grown as a mixed species cover crop in two commercial subtropical avocado (Persea americana Mill. cv. Hass) plantations. Legume biomass was assessed prior to mowing of the inter-row (fortnightly in summer and every 6-8 weeks over winter) and $\mathrm{N}$ fixation was estimated using the ${ }^{15} \mathrm{~N}$ natural abundance technique. Biomass production was $7377 \mathrm{~kg} \mathrm{ha}^{-1}$ (930 kg ha ${ }^{-1}$ for white clover and $6447 \mathrm{~kg} \mathrm{ha}^{-1}$ for Pinto peanut) at the first site over the 14-month period from December 2014 to January 2016, and $4467 \mathrm{~kg} \mathrm{ha}^{-1}$ (1114 kg ha ${ }^{-1}$ for white clover and $3353 \mathrm{~kg} \mathrm{ha}^{-1}$ for Pinto peanut) at the second site over the same period. Estimation of $\mathrm{N}$ fixation was not possible at the first site, due to a lack of difference in isotopic discrimination between the legume shoots and the reference plant (kikuyu (Pennisetum clandestinum Chiov.)) material. While legume shoots accumulated $157 \mathrm{~kg} \mathrm{~N} \mathrm{ha}^{-1}\left(38 \mathrm{~kg} \mathrm{ha}^{-1}\right.$ for white clover and $119 \mathrm{~kg} \mathrm{ha}^{-1}$ for Pinto peanut) across the season at site 1, the \% N derived from atmosphere (\%Ndfa) in legumes was relatively low (50-60\% in Pinto peanut during the warmer months and around 30\% in autumn and early spring, and from $13 \%$ in April to $69 \%$ in September for white clover). The low $\% \mathrm{Ndfa}$ in the legumes may have been due to low rainfall or molybdenum (Mo) deficiency. Ultimately the legume cover crops contributed an estimated $50 \mathrm{~kg}$ fixed $\mathrm{N} \mathrm{ha}^{-1}$, which could partially offset fertiliser $\mathrm{N}$ requirements of the tree crop. Our results demonstrate the need to quantify $\mathrm{N}$ fixation in legume cover crops to assess potential $\mathrm{N}$ benefits as opposed to relying on typical measurements of legume biomass and $\mathrm{N}$ accumulation.
\end{abstract}

Keywords: molybdenum; nitrogen fixation; Pinto peanut; white clover; ${ }^{15} \mathrm{~N}$ natural abundance; $\mathrm{N}$ cycling

\section{Introduction}

Inputs of nutrients, particularly nitrogen $(\mathrm{N})$, into tropical and subtropical fruit crops are essential to replace nutrient removed in harvested produce and maintain fruit yield and quality [1]. Avocados (Persea Americana Mill.) are one such crop, and applications of $\mathrm{N}$ fertiliser in excess of $100 \mathrm{~kg} \mathrm{~N} \mathrm{ha}^{-1}$ season $^{-1}$ are typical for high production avocado orchards [2], representing a significant cost to 
growers. In addition to the financial cost, the use of synthetic $\mathrm{N}$ fertilisers has been linked to a range of environmental issues, including potential eutrophication of waterways and increased greenhouse gas emissions through losses of nitrate $\left(\mathrm{NO}_{3}{ }^{-}\right)$and nitrous oxide $\left(\mathrm{N}_{2} \mathrm{O}\right)$, respectively [3,4]. In biological and organic farming systems the $\mathrm{N}$ fertiliser needs of crops are typically met through the application of manures or composts [5], which represent a significant cost of production and have associated energy costs associated with production, transport and spreading. Developing options to reduce the need for external $\mathrm{N}$ inputs may be a viable means of lowering the costs of production and minimising the environmental footprint of both conventional and organic subtropical fruit plantations.

The incorporation of $\mathrm{N}_{2}$-fixing leguminous crops into farming systems may be one means to reduce the need for external $\mathrm{N}$ inputs and decrease the environmental footprint associated with synthetic $\mathrm{N}$ fertilisers [6]. In perennial plantation crops the use of $\mathrm{N}_{2}$-fixing cover crops provides the added advantages of protecting the soil with consequent minimisation of erosion, and potential for harbouring beneficial insects to aid pest control [7]. A number of studies have examined potential for leguminous ground covers to produce biomass and accumulate $\mathrm{N}$ in tropical plantations [8,9]; however, few published estimates of fixed-N contributions from cover crops in the tropics or subtropics exist. One published report on $\mathrm{N}$ fixation in tropical rubber (Hevea brasiliensis L.) plantations suggests that as much as $150 \mathrm{~kg} \mathrm{~N} \mathrm{ha}^{-1}$ year $^{-1}$ can be fixed by legume cover crops [10], which could make a substantial contribution to the $\mathrm{N}$ requirements of the cash crop.

In a study on legume cover crops in the Australian subtropics, we found Pinto peanut (Arachis pintoi Krapov. \& W. C. Greg cv. Amarillo) fixed almost $150 \mathrm{~kg} \mathrm{~N} \mathrm{ha}^{-1}$ in shoots in a coffee (Coffea arabica L.) plantation, despite minimal growth and $\mathrm{N}$ fixation occurring during the cooler months [11]. Other legume species such as white clover (Trifolium repens L.) are productive over the winter/early spring period in the wet subtropics [12], raising the question as to whether a mixed legume sward may be productive across the entire season. The present study was thus initiated to investigate growth and $\mathrm{N}$ fixation of Pinto peanut and the winter/spring dominant white clover grown as a mixed species cover crop in subtropical avocado plantations. Nitrogen fixation was assessed using the ${ }^{15} \mathrm{~N}$ natural abundance method, which is a reliable method for assessing $\mathrm{N}$ fixation in the field provided the plant available soil $\mathrm{N}$ pools are sufficiently enriched in ${ }^{15} \mathrm{~N}$ compared to atmospheric $\mathrm{N}_{2}$ [13].

\section{Materials and Methods}

\subsection{Field Sites and Trial Design}

Growth and N fixation of Pinto peanut and white clover were investigated in replicated field plots in two commercial avocado plantations. The first site was a conventional farm that had existing groundcover of grasses and broadleaf weeds in the inter-row of avocado trees, with a history of herbicide and fungicide use and the application of synthetic fertilisers including urea at rates of $100-250 \mathrm{~kg} \mathrm{ha}^{-1}$ depending on the season. The second site had a history of 'biological' farming which was characterised by the absence of synthetic fertiliser (including $\mathrm{N}$ fertiliser) and any pesticides. External $\mathrm{N}$ inputs on this farm were traditionally provided by application of $5 \mathrm{th} \mathrm{a}^{-1}$ poultry litter per annum (roughly $125 \mathrm{~kg} \mathrm{~N} \mathrm{ha}^{-1}$ at around $10 \%$ moisture and $2.5-3 \% \mathrm{~N}$ ), but Pinto peanut was also grown in the inter-rows for the past 10 years and likely contributed fixed $\mathrm{N}$ to the system. Soils on both farms were classified as Rhodic Ferralsols [14] and chemical properties of the $0-100 \mathrm{~mm}$ layer of soil and mineral $\mathrm{N}$ concentrations to a depth of $1 \mathrm{~m}$ at each farm at the initiation of the trials are shown in Table 1. Soils were analysed at the Environmental Analysis Laboratory, Southern Cross University, Lismore, Australia, using methods from Rayment and Lyons [15]. Both sites were located near the town of Alstonville in North East New South Wales, Australia. The mean annual rainfall of the region (sourced from the Alstonville Tropical Fruit Research Station) is $1805 \mathrm{~mm}$ with the majority received over summer and autumn. Mean daily maximum temperatures range from $18.6{ }^{\circ} \mathrm{C}$ (July) to $27.2^{\circ} \mathrm{C}$ (January) and mean daily minimum temperatures range from $9.9^{\circ} \mathrm{C}$ (July) to $19.5^{\circ} \mathrm{C}$ (January). 
Table 1. Selected chemical properties of topsoils (0-10 $\mathrm{cm}$ depth) and mineral $\mathrm{N}$ to $90 \mathrm{~cm}$ depth at both sites.

\begin{tabular}{|c|c|c|}
\hline Soil Property (0-100mm) & Site 1 Tuckombil & Site 2 Alstonville \\
\hline Texture & Clay loam & Clay loam \\
\hline $\mathrm{pH}$ (1:5 Water) & 5.93 & 6.46 \\
\hline Total N (\%) & 0.35 & 0.41 \\
\hline Total C (\%) & 4.09 & 5.85 \\
\hline $\mathrm{EC}\left(\mathrm{dS} \mathrm{m}^{-1}\right)$ & 0.13 & 0.09 \\
\hline Bray 2 P (mg kg $\left.{ }^{-1}\right)$ & 23 & 7.6 \\
\hline Colwell $\mathrm{P}\left(\mathrm{mg} \mathrm{kg}^{-1}\right)$ & 114 & 58 \\
\hline Cation exchange capacity $\left(\mathrm{cmol}^{+} \mathrm{kg}^{-1}\right)$ & 7.7 & 10.6 \\
\hline \multicolumn{3}{|l|}{ Base cations $\left(\mathrm{cmol}^{+} \mathrm{kg}^{-1}\right)$} \\
\hline Calcium & 5.98 & 5.86 \\
\hline Magnesium & 1.13 & 3.17 \\
\hline Potassium & 0.44 & 1.15 \\
\hline Sodium & 0.09 & 0.20 \\
\hline \multicolumn{3}{|l|}{ DTPA-extractable micronutrients $\left(\mathrm{mg} \mathrm{kg}^{-1}\right)$} \\
\hline Zinc & 2.4 & 4.6 \\
\hline Manganese & 9.0 & 7.0 \\
\hline Iron & 102 & 206 \\
\hline Copper & 5.7 & 1.6 \\
\hline $\mathrm{CaCl}_{2}$-extratable $\mathrm{B}\left(\mathrm{mg} \mathrm{kg}^{-1}\right)$ & 0.95 & 1.1 \\
\hline \multicolumn{3}{|l|}{$\mathrm{KCl}$ extractable ammonium ( $\mathrm{mg} \mathrm{kg}^{-1}$ ) } \\
\hline $0-100 \mathrm{~mm}$ & 4.5 & 7.8 \\
\hline $100-300 \mathrm{~mm}$ & 5.0 & 4.1 \\
\hline $300-600 \mathrm{~m}$ & 6.4 & 3.3 \\
\hline $600-900 \mathrm{~mm}$ & 8.0 & 8.2 \\
\hline \multicolumn{3}{|l|}{$\mathrm{KCl}$ extractable nitrate $\left(\mathrm{mg} \mathrm{kg}^{-1}\right)$} \\
\hline $0-100 \mathrm{~mm}$ & 35 & 4.0 \\
\hline $100-300 \mathrm{~mm}$ & 109 & 4.7 \\
\hline $300-600 \mathrm{~m}$ & 79 & 4.2 \\
\hline $600-900 \mathrm{~mm}$ & 26 & 3.4 \\
\hline
\end{tabular}

At both sites, the groundcover legume plots were a part of a larger three $\mathrm{N}$ source treatment (legume cover crops, poultry litter or urea) $\times$ four replicate trial that compared nitrous oxide emissions from plots with legume cover crops to plots that received applications of urea or poultry litter. Trials were laid out in randomised block designs at both sites. In this paper we report only on the growth and potential $\mathrm{N}$ contributions of the legume cover crops treatments.

\subsubsection{Trial Site 1-Tuckombil NSW}

Site 1 was established at a commercial avocado planation at Tuckombil, NSW, Australia, on a block of 15-year-old 'Hass' avocado trees with rows spaced $9 \mathrm{~m}$ apart and a tree spacing of 6 within each row. The legume cover crop plots each contained a section of kikuyu (Pennisetum clandestinum Chiov.) grass (ranging from 1-1.5 $\mathrm{m}^{2}$ ) which was partitioned off and all pinto peanut within this section was hand weeded out. This grass was used as the non-N-fixing reference species for estimation of legume $\mathrm{N}$ fixation using the ${ }^{15} \mathrm{~N}$ natural abundance method (see below).

Because some Pinto peanut had been growing in the kikuyu section of the plots over the past 10 years, it was presumed that carryover of legume material (decomposed shoot material and root material) would likely confound estimations of $\mathrm{N}$ fixation using the ${ }^{15} \mathrm{~N}$ natural abundance method. To attempt to overcome this, the field site was maintained for 12 months without any $\mathrm{N}$ fixation measurements being taken to deplete residual $\mathrm{N}$ from the kikuyu section of the plots. During this period shoot material was mown off with a Honda self-propelled hand mower (in synchrony with the mowing operations of the plantation) and all shoot material was removed from plots. Harvest of 
plots for the purposes of determining annual biomass production and $\mathrm{N}$ fixation began in December 2014. In March 2015, white clover was over-sown into the pinto peanut cover crop plots at a rate of $3 \mathrm{~kg}$ seed ha ${ }^{-1}$. Seeds were inoculated with group B strain TA1.

\subsubsection{Trial Site 2-Alstonville New South Wales}

Site 2 was established at Alstonville, NSW, in a block of 4-year-old avocado trees planted in rows spaced $9 \mathrm{~m}$ apart with $5 \mathrm{~m}$ between trees within a row. Existing groundcover was predominantly kikuyu with a small component of Broadleaf paspalum (Paspalum mandiocanum). This ground cover had traditionally been managed by slashing every $2-3$ weeks in summer and every 5-6 weeks over winter. In the legume cover crops plots, existing grass and broadleaf ground cover was sprayed with glyphosate herbicide @ $2.5 \mathrm{~L} \mathrm{ha}^{-1}$ and Pinto peanut seedlings that had been raised for 6 months in the glasshouse at Southern Cross University were transplanted into plots in early February 2014 at a spacing of $200 \mathrm{~mm}$ between seedlings to establish the pinto peanut/white clover plots. These plots were oversown with inoculated white clover (cv. Haifa) seeds (broadcast at $3 \mathrm{~kg} \mathrm{ha}^{-1}$ ) in May 2014. A small $1 \mathrm{~m} \times 1 \mathrm{~m}$ area in each legume plots was retained under grass (kikuyu and broadleaf paspalum) for the purpose of obtaining shoot material from a non- $\mathrm{N}$-fixing reference crop for determination of $\mathrm{N}$ fixation using the ${ }^{15} \mathrm{~N}$ natural abundance method. Harvest of plots for the purposes of determining annual biomass production and N fixation began in December 2014 after the legumes had fully established within the plots.

\subsection{Biomass Production, N Accumulation and N Fixation in Legume Cover Crops}

From December 2014-January 2016, a $500 \mathrm{~mm} \times 500 \mathrm{~mm}$ section in each plot was cut by hand to determine pinto peanut and white clover biomass production before the remainder of the plot was mown off using the self-propelled hand mower. A sample of grass (non-legume reference species) was also harvested from each plot on each occasion of sampling. Any grass found in samples from the legume plots was removed in the laboratory at Southern Cross University and white clover was also separated from Pinto peanut in the biomass samples. All tissue samples were then dried in an oven for $5 \mathrm{~d}$ at $60^{\circ} \mathrm{C}$ and weighed. For white clover shoots harvested in spring (at flowering), a subsample of finely ground tissue $(0.2 \mathrm{~g})$ was digested with nitric acid in a MARS microwave oven (CEM Corp., Matthews, NC, USA). Concentrations of macronutrients $\mathrm{P}$, potassium $(\mathrm{K})$, magnesium $(\mathrm{Mg})$, calcium (Ca), and micronutrients $\mathrm{Zn}, \mathrm{Mn}$, iron (Fe), B, Mo and $\mathrm{Cu}$ in the digest solutions were ascertained using inductively coupled plasma optical emission spectroscopy (ICP-OES 4300D, Perkin Elmer, Waltham, MA, USA).

The $\mathrm{N}$ concentration in dried biomass samples was quantified by Dumas combustion of a $0.2 \mathrm{~g}$ subsample of finely ground tissue using a LECO TruMAC CNS analyser (LECO Corporation, MI, USA). Legume $\mathrm{N}$ accumulation in was calculated by multiplying the tissue $\mathrm{N}$ concentration by the respective tissue biomass. All shoot biomass and $\mathrm{N}$ accumulation data were expressed on a calendar month basis using the method described in Rose et al. [11].

Nitrogen isotope ratios were measured using a Thermo Delta V plus isotope ratio mass spectrometer (Thermo Scientific, Bremen, Germany) following combustion on a Thermo Flash EA 1112 elemental analyser (Thermo Scientific, Bremen, Germany). The $\% \mathrm{~N}$ derived from atmosphere (\%Ndfa) in Pinto peanut and white clover shoots was calculated as per Shearer and Kohl [16]:

$$
\% \mathrm{Ndfa}=\frac{100\left(\delta^{15} \mathrm{~N} \text { reference plant }-\delta^{15} \mathrm{~N}\right. \text { legume }}{\left(\delta^{15} \mathrm{~N} \text { reference plant }-\mathrm{B}\right)}
$$

where the reference plant was kikuyu and the B value describes the extent of isotopic fractionation that occurs during the $\mathrm{N}$ fixation process. The $\mathrm{B}$ value used for Pinto peanut was $-0.2 \%$ as previously determined by Rose et al. [11] for $30 \mathrm{~d}$ old shoots. The $\mathrm{B}$ value for white clover was determined by growing white clover (cv. Haifa) inoculated with group B strain TA1 rhizobia in N-free sand-culture 
in the glasshouse at Southern Cross University, Lismore, NSW, Australia. All nutrients other than N were provided in the irrigation solution as per Rose et al. [17]. At 50 days after sowing shoots were harvested about $10 \mathrm{~mm}$ above the soil surface from three replicate pots and $\mathrm{N}$ isotope ratios in shoot material was determined as described above. The mean B value derived was $-2.75 \%$.

The biomass was multiplied by the respective \%Ndfa for each plant cut for white clover and Pinto peanut to determine fixed N. Fixed $\mathrm{N}$ data were converted to a per calendar month basis via the same method used express shoot biomass and shoot $\mathrm{N}$ accumulation data on a calendar month basis (see above). Average monthly \%Ndfa for white clover and Pinto peanut was then back-calculated by dividing the estimated fixed $\mathrm{N}$ per month by the respective monthly biomass production.

\section{Results}

\subsection{Dry Matter Production}

At the Tuckombil site cumulative biomass production was $7377 \mathrm{~kg} \mathrm{ha}^{-1}\left(930 \mathrm{~kg} \mathrm{ha}^{-1}\right.$ for white clover and $6447 \mathrm{~kg} \mathrm{ha}^{-1}$ for Pinto peanut) over the 14 month period from December 2014 to January 2016, while cumulative biomass production at the Alstonville site for the same period was $4467 \mathrm{~kg} \mathrm{ha}^{-1}$ (1114 kg ha ${ }^{-1}$ for white clover and $3353 \mathrm{~kg} \mathrm{ha}^{-1}$ for Pinto peanut) (Figure 1a,c). Notably, this production only occurred in $75 \%$ of the plantation, since around $25 \%$ of the area (directly under avocado trees) is covered in leaf mulch and has no legumes present. Pinto peanut growth occurred predominantly in summer at both sites while white clover biomass production peaked in late winter/early spring.
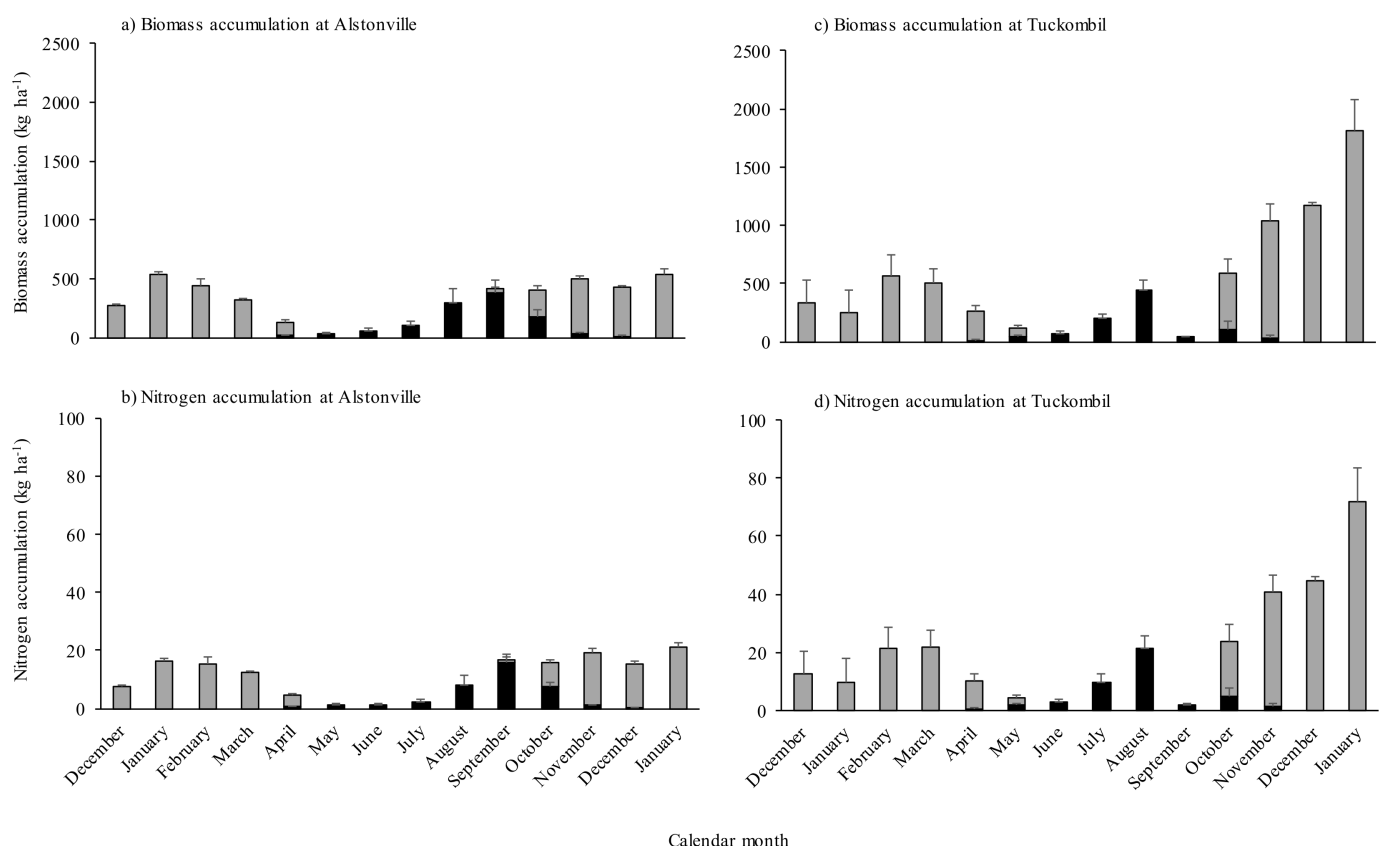

Figure 1. Pinto peanut and white clover biomass production at Alstonville (a) and Tuckombil (b), and nitrogen accumulation to Alstonville (c) and Tuckombil (d) in the 2015 calendar year. Grey shading indicates Pinto peanut and black shading indicates white clover. Error bars are SEM $(n=4)$.

\subsection{Nitrogen Fixation and $N$ Accumulation in Shoots}

Shoot $\mathrm{N}$ accumulation in the legumes mirrored the biomass production across the 14 month period, amounting to $297 \mathrm{~kg} \mathrm{ha}^{-1}$ (44 kg ha ${ }^{-1}$ for white clover and $253 \mathrm{~kg} \mathrm{ha}^{-1}$ for Pinto peanut) at Tuckombil and $157 \mathrm{~kg} \mathrm{ha}^{-1}$ (38 kg ha ${ }^{-1}$ for white clover and $119 \mathrm{~kg} \mathrm{ha}^{-1}$ for Pinto peanut) at Alstonville (Figure $1 \mathrm{~b}, \mathrm{~d}$ ). At the Alstonville site, mean $\delta^{15} \mathrm{~N}$ values for the kikuyu reference samples at each harvest ranged from 4.6 to $6.0 \%$, while mean $\delta^{15} \mathrm{~N}$ values for Pinto peanut and white clover ranged from 1.8 to $4.4 \%$ and -1 to $3.0 \%$, respectively. Pinto peanut \%Ndfa was $50-60 \%$ during the 
warmer months but was only around 30\% in autumn and early spring (Table 2). White clover mean $\%$ Ndfa increased from April (13\%) to September (69\%) before declining to 39\% by November (Table 2). Over the 2015 calendar year Pinto peanut fixed an estimated $40.3 \mathrm{~kg} \mathrm{~N} \mathrm{ha}^{-1}$ in plots while white clover fixed an estimated $26.1 \mathrm{~kg} \mathrm{~N} \mathrm{ha}^{-1}$ in plots (Table 2). Given that around $25 \%$ of the plantation area (under the avocado trees) is covered by leaf mulch and did not have legumes present, the total contribution of legumes to the plantation was estimated to be $50 \mathrm{~kg} \mathrm{~N} \mathrm{ha}^{-1}$.

Table 2. \%Ndfa and $\mathrm{N}$ fixed per month for Pinto peanut and white clover at the Alstonville site. Means are followed by standard errors $(n=4)$.

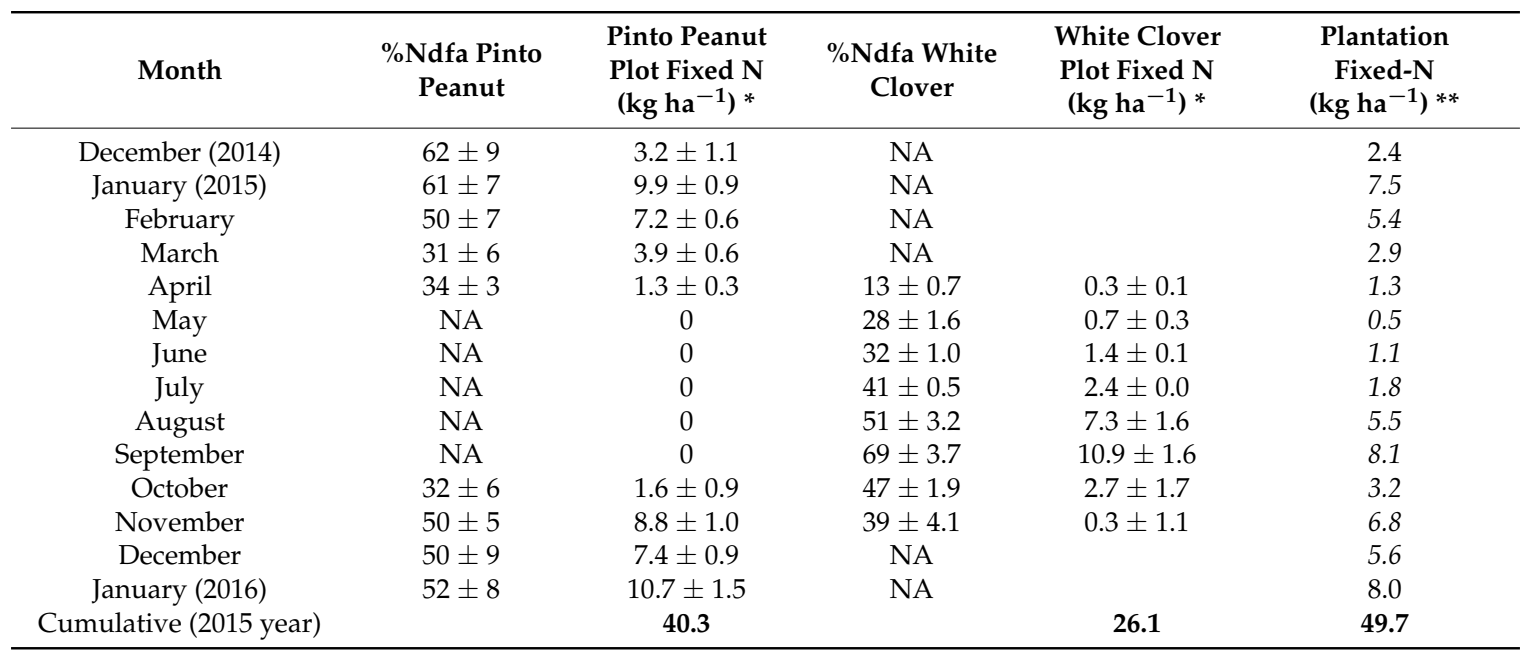

* Plot fixed $\mathrm{N}$ was calculated by multiplying the total $\mathrm{N}$ in shoots by the respective \%Ndfa. ${ }^{*}$ Plantation fixed-N accounts for the fact that around $25 \%$ of the plantation - the area directly under avocado trees-is covered in leaf mulch and did not have legumes growing. Plantation fixed-N values in italics were summed to estimate the 2015 calendar year cumulative fixed-N.

Estimation of the proportion of $\mathrm{N}$ in shoot material that was fixed from the atmosphere was not possible at Tuckombil using the ${ }^{15} \mathrm{~N}$ natural abundance method, owing to a lack of difference in isotopic discrimination between the legume shoots and reference plant (kikuyu) material. Mean $\delta^{15} \mathrm{~N}$ values for both the kikuyu reference samples and legume samples ranged from 1 to $4 \%$ for the first two harvests. On this basis, tissue $\mathrm{N}$ isotope ratios were not analysed for the remainder of the study at the Tuckombil site.

\section{Discussion}

While a range of studies have reported on the growth of legume cover crops in perennial tree plantations, very few have quantified fixed-N contributions by the cover crops. The estimated fixed $\mathrm{N}$ contribution of around $50 \mathrm{~kg} \mathrm{~N} \mathrm{ha}^{-1}$ year $^{-1}$ in the mixed Pinto peanut/white clover cover crop at the Alstonville site is substantially less that the $150 \mathrm{~kg} \mathrm{~N} \mathrm{ha}^{-1}$ year $^{-1}$ reported in Pinto peanut cover crops in coffee plantations in the same region [11] or from legume cover crops in tropical rubber plantations [10]. This was partially due to around $25 \%$ of the plantation area being covered in leaf mulch with no legumes present (immediately under the avocado trees) but also due to low average \%Ndfa in the legumes, and low biomass production in the legumes at the Alstonville site (4467 kg ha ${ }^{-1}$ over 14 months) compared to Tuckombil (7377 kg ha ${ }^{-1}$ over 14 months). Poor spring growth in legume cover crops at Alstonville was likely due to low rainfall, with only two rainfall events exceeding $15 \mathrm{~mm}$ from July-October 2015 (Supplementary Figure S1). Similar differences in N fixation in legume cover crops in olive groves have been reported between sites in the same region (e.g., 179 vs. $113 \mathrm{~kg} \mathrm{~N} \mathrm{ha}^{-1}$ year $^{-1}$ ) [18], presumably due to inherent differences in soil fertility and rainfall at the sites. However, it is also possible that the difference in the age of the Pinto peanut 
stands (around 1 year at Alstonville vs. $>10$ years at Tuckombil) contributed to differences biomass in productivity.

Soil fertility may also have influenced legume $\mathrm{N}$ fixation as well as biomass production. The range of $\% \mathrm{Ndfa}$ in Pinto peanut from around 30\% in late autumn or early spring to over $60 \%$ in summer at the Alstonville site is lower than the range of $55-79 \%$ reported in coffee plantations in the same region in the same year [11], and \%Ndfa in white clover ranged from 13\% in April to $69 \%$ in September. While high soil mineral $\mathrm{N}$ levels can reduce $\mathrm{N}$ fixation [19], the mineral $\mathrm{N}$ levels at the Alstonville site were low throughout the profile at the initiation of the study (Table 1) and the presence of roots of actively growing avocado trees in the inter-row would more than likely have kept soil mineral $\mathrm{N}$ levels relatively throughout the experimental period. However, deficiencies of macronutrients including phosphorus (P) [20] or micronutrients such as molybdenum (Mo) [21] are often linked to poor nodule function and low rates of $\mathrm{N}$ fixation in legumes. Indeed, a strong association between legume Mo uptake and biological $\mathrm{N}$ fixation has been reported on Rhodic Ferralsols in the same district as the present field experiment [22]. While no critical soil Mo thresholds have been derived for legumes on these soils and no critical tissue test levels are available for Pinto Peanut in the literature, Mo concentrations of $0.4-1.0 \mathrm{mg} \mathrm{kg}^{-1}$ in whole tops at flowering are required for adequate white clover growth [23]. Given that the concentration of Mo in whole tops of white clover during the flowering period in spring was less than the $0.5 \mathrm{mg} \mathrm{kg}^{-1}$ detection limit (Supplementary Table S1), it is quite possible that Mo deficiency contributed to the low rates of legume $\mathrm{N}$ fixation at the Alstonville site. Whole shoot copper (Cu), zinc ( $\mathrm{Zn})$, manganese (Mn) and boron (B) concentrations of 9.6, 34.2, 66.0, and $28.9 \mathrm{mg} \mathrm{kg}^{-1}$, respectively (Supplementary Table S1), were all above the reported critical levels white clover [23]. Ultimately, to optimise $\mathrm{N}$ contributions from leguminous cover crops in perennial tree crop systems it may be necessary to pay attention to soil nutrient levels in the inter-row in addition to those in the tree line. Our results also highlight the fact that the standard measurements of biomass and $\mathrm{N}$ accumulation in legume cover crops $[8,9]$ are not sufficient to extrapolate $\mathrm{N}$ contributions of legume cover crops.

Notably, we only estimated $\mathrm{N}$ fixation in shoots, and any potential $\mathrm{N}$ contributions from legume roots were not accounted for. These contributions may be substantial for many legumes [24], including pasture legume species [25]. We further acknowledge that there are a number of potential sources of error inherent when employing the ${ }^{15} \mathrm{~N}$ natural abundance method to calculate fixed-N in legumes (see Peoples et al. [24] for discussion of some of these factors), and therefore the fixed-N contributions measured in this study represent an estimate only. In particular, the B value used for a given legume cultivar can depend on the age of the plant [26], and we used a B value derived from 30-day old shoots while field samples ranged from 2-6-week old shoots. Nonetheless, and in light of the dearth of published estimates of $\mathrm{N}$ fixation by legume cover crops, we believe our study provides a reasonable and useful estimate of cumulative seasonal $\mathrm{N}$ fixation by the legume cover crops cultivated. It is further noted that the ${ }^{15} \mathrm{~N}$ natural abundance method was not able to estimate $\mathrm{N}$ fixation at the Tuckombil site due to a lack of difference in isotopic discrimination between the legume shoots and non-N-fixing reference plant (kikuyu). Other $\mathrm{N}$ fixation estimation techniques involving ${ }^{15} \mathrm{~N}$ labelling could be used in such situations (for a discussion on these techniques and their limitations see Unkovich et al. [13]), but like the ${ }^{15} \mathrm{~N}$ natural abundance method, these techniques require access to specialised isotope ratio mass spectrometry equipment.

Given that high performing avocado plantations typically receive $\mathrm{N}$ fertiliser applications in excess of $100 \mathrm{~kg} \mathrm{~N} \mathrm{ha}^{-1}$ season $^{-1}$ [2], it appears that $\mathrm{N}$ contributions from cover crop legumes may not be able to fully replace external inputs, but may facilitate some reductions in external N inputs. Further research is required to understand the release patterns of $\mathrm{N}$ from legume residues, the percent recovery of this $\mathrm{N}$ by avocado trees, and finally the extent to which external $\mathrm{N}$ fertiliser applications may be reduced. 
Supplementary Materials: The following are available online at http://www.mdpi.com/2073-4395/9/2/70/s1, Figure S1: Rainfall and daily maximum temperature data for the experimental period at (a) the Tuckombil site and (b) the Alstonville site, Table S1: Nutrient concentration in whole shoots of white clover at flowering at the Alstonville site.

Author Contributions: T.J.R. conceived and designed the experiments, T.J.R. and L.J.K. undertook experiments, analysed the Data and wrote the paper.

Funding: The work was funded by the Australian Department of Agriculture Action on the Ground program of the Carbon Farming Initiative (project AoTG2-0026).

Conflicts of Interest: The authors declare no conflicts of interest.

\section{References}

1. Huett, D.O.; Dirou, J.F. An evaluation of the rationale for fertiliser management of tropical fruit crops. Aust. J. Exp. Agric. 2000, 40, 1137-1143. [CrossRef]

2. Lovatt, C.J. Properly timed soil-applied nitrogen fertilizer increases yield and fruit size of 'Hass' avocado. J. Am. Soc. Hort. Sci. 2001, 126, 555-559. [CrossRef]

3. Masso, C.; Baijukya, F.; Ebanyat, P.; Bouaziz, S.; Wendt, J.; Bekunda, M.; Vanlauwe, B. Dilemma of nitrogen management for future food security in sub-Saharan Africa-A review. Soil Res. 2017, 55, 425-434. [CrossRef]

4. Rose, T.J.; Morris, S.J.; Quin, P.; Kearney, L.J.; Kimber, S.; Van Zwieten, L. The nitrification inhibitor DMPP applied to subtropical rice has an inconsistent effect on nitrous oxide emissions. Soil Res. 2017, 55, 547-552. [CrossRef]

5. Rempelos, L.; Almuayrifi, A.M.; Baranski, M.; Tetard-Jones, C.; Eyre, M.; Shotton, P.; Cakmak, I.; Ozturk, L.; Cooper, J.; Volakakis, N.; et al. Effects of agronomic management and climate on leaf phenolic profiles, disease severity and grain yield in organic and conventional wheat production systems. J. Agric. Food Chem. 2018. [CrossRef] [PubMed]

6. Jensen, E.S.; Peoples, M.B.; Boddey, R.M.; Gresshoff, P.M.; Hauggaard-Nielsen, H.; Alves, B.J.R.; Morrison, M.J. Legumes for mitigation of climate change and the provision of feedstock for biofuels and biorefineries. A review. Agron. Sustain. Dev. 2012, 32, 329-364. [CrossRef]

7. Hartwig, N.L.; Ammon, H.U. Cover crops and living mulches. Weed Sci. 2002, 50, 688-699. [CrossRef]

8. Santos, J.C.F.; da Cunha, A.J.; Ferreira, F.A.; Santos, R.H.S.; Sakiyama, N.S.; de Lima, P.C. Herbaceous legumes intercropping in weed management of the coffee crop. J. Agric. Environ. Sci. 2016, 5, 91-100.

9. Snoeck, D.; Zapata, F.; Domenach, A.-M. Isotopic evidence of the transfer of nitrogen fixed by legumes to coffee trees. Biotechnol. Agron. Soc. Environ. 2000, 4, 95-100.

10. Agamuthu, P.; Broughton, W.J. Nutrient cycling within the developing oil palm-legume ecosystem. Agric. Ecosys. Environ. 1985, 13, 111-123. [CrossRef]

11. Rose, T.J.; Kearney, L.J.; Morris, S.G.; Van Zwieten, L.; Erler, D.V. Pinto peanut cover crop nitrogen contributions and potential to mitigate nitrous oxide emissions from subtropical coffee plantations. Sci. Total Environ. 2019, 656, 108-117. [CrossRef]

12. Fulkerson, W.J.; Slack, K. Management of Lolium perenne/Trifolium repens pastures in the subtropics. II. Effect of summer defoliation, irrigation duration, seedbed preparation and pasture type. Aust. J. Agric. Res. 1994, 45, 721-728. [CrossRef]

13. Unkovich, M.; Herridge, D.; Peoples, M.; Cadisch, G.; Boddey, R.; Giller, K.; Alves, B.; Chalk, P. Measuring Plant-Associated Nitrogen Fixation in Agricultural Systems; ACIAR Monograph No. 136: Canberra, Australia, 2008.

14. FAO-UNESCO. Soil Map of the World. Food and Agriculture Organization of the United Nations: Rome, Italy, 1974.

15. Rayment, G.E.; Lyons, D.J. Australian Laboratory Handbook of Soil and Water Chemical Methods; Inkata Press: Port Melbourne, Australia, 2011.

16. Shearer, G.; Kohl, D.H. $\mathrm{N}_{2}$ fixation in field settings: Estimations based on natural ${ }^{15} \mathrm{~N}$ abundance. Aust. J. Plant Physiol. 1986, 13, 699-756.

17. Rose, T.J.; Rengel, Z.; Ma, Q.; Bowden, J.W. Post-flowering supply of P, but not K, is required for maximum canola seed yields. Eur. J. Agron. 2008, 28, 371-379. [CrossRef]

18. Ferreira, I.Q.; Rodrigues, M.A.; Claro, A.M.; Arrobas, M. Management of nitrogen-rich legume cover crops as mulch in traditional olive orchards. Commun. Soil Sci. Plant Anal. 2015, 46, 1881-1894. [CrossRef] 
19. Streeter, J. Inhibition of legume nodule formation and $\mathrm{N}_{2}$ fixation by nitrate. Crit. Rev. Plant Sci. 1988, 7 , 1-23. [CrossRef]

20. Tang, C.; Hinsinger, P.; Drevon, J.J.; Jaillard, B. Phosphorus deficiency impairs early nodule functioning and enhances proton release in roots of Medicago truncatula L. Ann. Bot. 2001, 88, 131-138. [CrossRef]

21. Kaiser, B.N.; Gridley, K.L.; Brady, J.N.; Phillips, T.; Tyerman, S.D. The role of molybdenum in agricultural plant production. Ann. Bot. 2005, 96, 745-754. [CrossRef] [PubMed]

22. Van Zwieten, L.; Rose, T.J.; Herridge, D.; Kimber, S.; Rust, J.; Cowie, A.; Morris, S. Enhanced biological $\mathrm{N}_{2}$ fixation and yield of faba bean (Vicia faba L.) in an acid soil following biochar addition: Dissection of causal mechanisms. Plant Soil 2015, 395, 7-20. [CrossRef]

23. Reuter, D.J.; Robinson, J.B. Plant Analysis: An Interpretation Manual, 2nd ed.; CSIRO Publishing: Collingwood, Australia, 1997.

24. Peoples, M.B.; Brockwell, J.; Hunt, J.R.; Swan, A.D.; Watson, L.; Hayes, R.C.; Li, G.D.; Hackney, B.; Nuttall, J.G.; Davies, S.L.; et al. Factors affecting the potential contributions of $\mathrm{N}_{2}$ fixation by legumes in Australian pasture systems. Crop Pasture Sci. 2012, 63, 759-786. [CrossRef]

25. Høgh-Jensen, H.; Schjoerring, J.K. Rhizodeposition of nitrogen by red clover, white clover and ryegrass leys. Soil Biol. Biochem. 2001, 33, 439-448.

26. Rose, T.J.; Kearney, L.J.; Erler, D.V.; Rose, M.T.; Van Zwieten, L.; Raymond, C.A. Influence of growth stage and seed nitrogen on $B$ values and potential contributions to error in estimating biological $\mathrm{N}_{2}$ fixation using the ${ }^{15} \mathrm{~N}$ natural abundance method. Plant Soil 2018, 425, 389-399. [CrossRef]

(C) 2019 by the authors. Licensee MDPI, Basel, Switzerland. This article is an open access article distributed under the terms and conditions of the Creative Commons Attribution (CC BY) license (http:/ / creativecommons.org/licenses/by/4.0/). 